\title{
PERTANGGUNGJAWABAN PIDANA KONTRAKTOR ATAS KEGAGALAN BANGUNAN BERDASARKAN PRINSIP SISTEM PERTANGGUNGJAWABAN PIDANA KORPORASI
}

\author{
Diah Pudjiastuti \\ Program Studi Magister Ilmu Hukum \\ Pascasarjana Universitas Islam Bandung \\ e-mail : Tamazka.pudjiastuti2531@gmail.com
}

\begin{abstract}
Abstrak - Pembangunan sangat bermanfaat bagi kehidupan manusia, namun tidak luput dari kerugian baik kerugian materiil maupun korban jiwa jika tidak dibangun sebagaimana mestinya. Salah satunya adalah runtuhnya jembatan kutai kartanegara yang menyebabkan orang meninggal dunia dan luka-luka. Kegagalan bangunan merupakan salah satu akibat yang dapat membahayakan keselamatan publik maupun kerugian negara. Kegagalan bangunan ini diatur secara eksplisit dalam Undang-Undang Nomor 2 Tahun 2017 Tentang Jasa Konstruksi mulai dari Pasal 60 sampai dengan Pasal 67. Selain itu kegagalan bangunan diatur di dalam Peraturan Pemerintah Nomor 29 Tahun 2000 Tentang Penyelenggaraan Jasa Konstruksi yaitu pada Bab V Pasal 34 sampai dengan Pasal 48. Pertanggungjawaban pidana berdasarkan Undang-Undang Jasa Konstruksi hanya dapat dikenakan pada individu yang secara langsung melaksanakan pekerjaan konstruksi dan tidak pada penyedia jasa konstruksi berupa korporasi karena untuk memidana korporasi membutuhkan kejelasan kepada siapa sanksi akan dikenakan. Berdasarkan hasil analisis bahwa berdasarkan teori pertanggungjawaban pidana, dengan adanya pergeseran subjek hukum dari fysieke dader ke functionale dader maka korporasi dapat dimintakan pertanggungjawaban. Hal tersebut juga didukung dengan adanya teori-teori serta doktrindoktrin tentang pertanggungjawaban korporasi. Dengan lahirnya Peraturan Mahkamah Agung Nomor 13 tahun 2016 tentang Tata Cara Penanganan Perkara Tindak Pidana Oleh Korporasi, dimana hal ini dimaksudkan sebagai upaya memberikan kepastian hukum dan mendorong efektivitas dan optimalisasi atas hukum acara dalam penangangan perkara pidana dengan pelaku korporasi dan/atau pengurus korporasi.
\end{abstract}

Kata Kunci : Pertangungjawaban Pidana, Kontraktor, Kegagalan Bangunan

Abstract - Development is very beneficial for human life, but does not escape the loss of both material losses and loss of life if it is not built properly. One of them is the collapse of the Kutai Kartanegara bridge which caused people to die and be injured. Building failure is one of the consequences that can endanger public safety and state losses. This building failure is regulated explicitly in Law Number 2 of 2017 concerning Construction Services starting from Article 60 to Article 67. In addition, building failures are regulated in Government Regulation Number 29 of 2000 concerning the Implementation of Construction Services, namely in Chapter V Article 34 to with Article 48. Criminal liability under the Construction Services Act can only be imposed on individuals who directly carry out construction work and not on construction service providers in the form of corporations because to convict corporations requires clarity to whom sanctions will be imposed. Based on the results of the analysis that based on the theory of criminal liability, 
with the shift of legal subjects from daddy to physie dader, the corporation can be held accountable. This is also supported by the existence of theories and doctrines about corporate responsibility. With the birth of the Supreme Court Regulation Number 13 of 2016 concerning Procedures for Handling Criminal Cases by Corporations, this is intended as an effort to provide legal certainty and encourage the effectiveness and optimization of procedural law in handling criminal cases with corporate actors and / or corporate administrators.

Keywords: Criminal Responsibility, Contractor, Building Failure

\section{A. PENDAHULUAN}

Negara adalah suatu organisasi yang memiliki tujuan. Pada konteks negara Indonesia, tujuan negara tertuang dalam alinea keempat Pembukaan UUD 1945, yang mengidentifikasikan bahwa Indonesia merupakan negara hukum yang menganut konsep welfare state (negara kesejahteraan). Sebagai negara hukum yang bertujuan mewujudkan kesejahteraan umum, setiap kegiatan di samping harus diorientasikan pada tujuan yang hendak dicapai juga harus berdasarkan pada hukum yang berlaku sebagai aturan kegiatan kenegaraan, pemerintahan, dan kemasyarakatan. ${ }^{1}$

Didalam pertimbangan huruf a Peraturan Mahkamah Agung Nomor 13 Tahun 2016 Tentang tata cara penanganan perkara tindak pidana oleh korporasi mengatakan, bahwa korporasi

1 Juniarso Ridwan, Achmad Sodik Sudrajat, Hukum Administrasi Negara Dan Kebijakan Layanan Publik, Nuansa Cendekia, Bandung, 2014, Hlm. 11 sebagai suatu entitas atau subjek hukum yang keberadaannya memberikan konstribusi yang besar dalam meningkatkan pertumbuhan ekonomi dan pembangunan nasional, namun dalam kenyataannya korporasi ada kalanya juga melakukan berbagai tindak pidana (corporate crime) yang membawa dampak kerugian terhadap negara dan masyarakat.

Di dalam sistem pertanggungjawaban pidana korporasi, masih banyak kelemahan formulasi. Akibat kelemahan tersebut membawa dampak bahwa korporasi sebagai subjek tindak pidana jarang dituntut secara pidana. Atas hal tersebut maka, yurisprudensi yang mengatur masalah korporasi sebagai tindak pidana sulit sekali ditemukan. ${ }^{2}$ Padahal hukum memiliki dimensi untuk menunjang

\footnotetext{
${ }^{2}$ Dwidja Priyatno, Kebijakan Legislasi Tentang Sistem Pertanggungjawaban Pidana Korporasi Di Indonesia, CV Utomo, Bandung, 2003, Hlm. 141
} 
pembangunan nasional suatu bangsa, melalui perundang-undangan yang dirancang secara khusus untuk menggerakkan pembangunan dengan memobilisasi dan memotivasi masyarakat sebagai pelaku pembangunan, termasuk aparatur pemerintahan terkait. ${ }^{3}$

Menurut ajaran vicarious liability, seseorang dimungkinkan untuk bertanggungjawab terhadap perbuatan orang lain. Jika ajaran ini diterapkan pada korporasi, korporasi dimungkinkan harus bertanggungjawab atas perbuatanperbuatan yang dilakukan oleh pegawainya, kuasanya atau mandatarisnya atau siapa saja yang bertanggungjawab kepada korporasi tersebut. Doktrin ini dikenal dengan pertanggungjawaban pengganti, pertanggungjawaban menurut hukum dimana seseorang atas perbuatan salah yang dilakukan oleh orang lain. ${ }^{4}$

Kondisi jasa konstruksi nasional terkadang tidak mencerminkan harapanharapan dalam mewujudkan suatu

\footnotetext{
3 Dey Ravena, Kristian, Kebijakan Kriminal, Kencana, Jakarta, 2017, Hlm. 97

4 Rinto Wardana, Tanggungjawab Pidana Kontraktor Atas Kegagalan Bangunan Menerobos Dominasi Maxim Societas/Universitas Delinquere Non Potest, Media Nusa Creative, Malang, 2016, Hlm.60-61
}

bangunan yang berkualitas dan mampu berfungsi seperti yang direncanakan. ${ }^{5}$

Kondisi ini tercermin dalam kegagalan proyek infrastrukstur beberapa tahun terakhir ini, diantaranya yaitu :

1. Selasar Gedung Bursa Efek Indonesia (BEI) ambruk pada hari senin tanggal 15 januari 2018 hal tersebut diduga menyalahi spesifikasi yang menyebabkan kegagalan bangunan tersebut, menurut Sekjen Gabungan Pelaksana Konstruksi Indonesia (Gapensi) Andi Rukman Karumpa. ${ }^{6}$

2. Runtuhnya jembatan Kutai Kartanegara pada tanggal 26 November 2011 pukul 16:20 waktu setempat dengan kontraktor PT. Hutama Karya yang menangani proyek pembangunan tersebut, sedangkan pada proyek pemeliharaan jembatan dengan kontraktor PT. Bukaka Teknik Utama, yang menyebabkan 21 
orang meninggal dunia dan lukaluka berdasarkan hasil visum et repertum berdasarkan Putusan Pengadilan Nomor: 103/PID.B/2012/PN.Tgr serta mengakibatkan beberapa orang masyarakat pengguna jembatan beserta kendarannya ikut terjatuh dan tenggelam ke dalam sungai Mahakam. $^{7}$

Peraturan Pemerintah No. 29 Tahun 2000 tentang Penyelenggaraan Jasa Konstruksi di Indonesia, yang tertuang dalam Pasal 35 ayat 1 disebutkan bahwa jangka waktu pertanggungjawaban atas kegagalan bangunan ditentukan sesuai dengan umur konstruksi yang direncanakan dengan maksimal 10 (sepuluh) tahun, sejak penyerahan akhir pekerjaan konstruksi (Final Hand Over/FHO).

Berdasarkan Pasal 1 angka 3 Undang-Undang No. 2 Tahun 2017 Tentang Jasa Konstruksi menyebutkan bahwa pekerjaan konstruksi adalah keseluruhan atau sebagian kegiatan yang meliputi pembangunan, pengoperasian, pemeliharaan, pembongkaran, dan pembangunan kembali suatu bangunan,

\begin{tabular}{|c|c|c|}
\hline Putusan & Pengadilan & Nomor \\
\hline
\end{tabular}

sedangkan kegagalan bangunan menurut Pasal 1 angka 10 Undang-Undang No. 2 Tahun 2017 Tentang Jasa Konstruksi adalah suatu keadaan keruntuhan bangunan dan/atau tidak berfungsinya bangunan setelah penyerahan akhir hasil jasa konstruksi.

Penegakan hukum dan keadilan merupakan serangkaian proses yang cukup panjang dan dapat melibatkan berbagai instansi atau pejabat negara. Peraturan perundang-undangan dan penegakan hukum harus bertujuan untuk mengubah pola pemikiran setiap penegak hukum dan masyarakat untuk mengantisipasi dan mengatasi pola kejahatan yang semakin kompleks. ${ }^{8}$

Atas dasar latar belakang diatas maka yang menjadi persoalan yaitu bagaimana pertanggungjawaban pidana kontraktor atas terjadinya insiden runtuhnya Jembatan Kutai Kartanegara yang mengakibatkan korban mati dan luka berdasarkan sistem pertanggungjawaban pidana korporasi dan bagaimana implementasi pertanggungjawaban pidana kontraktor atas terjadinya insiden runtuhnya Jembatan Kutai Kartanegara berdasarkan

\footnotetext{
${ }^{8}$ Edi Setiadi, Kristian, Sistem Peradilan Pidana Terpadu Dan Sistem Penegakan Hukum Di Indonesia, Kencana, Jakarta, 2017, Hlm. 132-133
} 
Peraturan Mahkamah Agung No. 13 Tahun 2016 Tentang Tata Cara Penanganan Perkara Tindak Pidana Oleh Korporasi.

Pada umumnya, pertanggungjawaban pidana korporasi diawali oleh perbuatan-perbuatan dalam lingkup perdata yang dilakukan oleh pengurus korporasi, tetapi dari perbuatanperbuatan dalam hukum keperdataan juga diikuti oleh sifat melawan hukumnya perbuatan yang dilakukan oleh pengurus korporasi. Perbuatan-perbuatan yang bersifat melawan hukum dari pengurus korporasi akan menggambarkan sifat melawan hukumnya perbuatan korporasi. ${ }^{9}$

Didalam Undang- Undang No. 40 Tahun 2007 Tentang Perseroan Terbatas Pasal 82, Pasal 84, dan Pasal 85 dapat dilihat tanggungjawab direksi atau pengurus perseroan dalam menjalankan tugas-tugasnya.

"Direksi bertanggungjawab penuh atas pengurusan perseroan untuk kepentingan dan tujuan serta mewakili perseroan, baik di dalam maupun di luar

9 Agus Rusianto, Tindak Pidana dan Pertanggungjawaban Pidana Tinjauan Kritis Melalui Konsistensi Antara Asas, Teori dan Penerapannya, Prenadamedia Group, Jakarta, 2016, Hlm. 243
pengadilan”.(Pasal 82 UU No. 40

Tahun 2007).

Dalam sistem hukum pidana, terdapat beberapa teori yang dapat dipergunakan untuk menentukan dasardasar yang patut, agar korporasi dapat dimintai pertanggungjawaban pidana, seperti teori pertanggungjawaban atas kesalahan (liability based onfault). ${ }^{10}$ Selain itu dikenal adanya pertanggungjawaban pengganti (vicarious liability doctrine). Kejahatan atau tindak pidana korporasi juga dikenal sebagai kejahatan bisnis. Kejahatan atau tindak pidana korporasi selalu dilakukan dalam bisnis skala besar (big business). ${ }^{11}$

\section{B. PEMBAHASAN}

1. Pertanggungjawaban Pidana Kontraktor Atas Insiden Runtuhnya Jembatan Kutai Kartanegara Yang Mengakibatkan Korban Mati Dan Luka Berdasarkan Sistem Pertanggungjawaban Pidana Korporasi

\footnotetext{
10 Rufinus Hotmaulana Hutauruk, Penanggulangan Kejahatan Korporasi Melalui Pendekatan Restoratif Suatu Terobosan Hukum, Sinar Grafika, Jakarta, 2014, Hlm. 48

${ }^{11}$ Kristian, Kejahatan Korporasi Di Era Modern \& Sistem Pertanggungjawaban Pidana Korporasi, Refika Aditama, Bandung, 2016, Hlm. 23
} 
Dalam pertimbangan tersebut terlihat Majelis Hakim berpendapat bahwa unsur barangsiapa adalah orang sebagai pendukung hak dan kewajiban. Dimana, dalam perkara yang dimaksud dalam putusan nomor 103/PID.B/2012/PN.Tgr adalah Muhammad Syahriar Fakhrurrozi, ST bin Noor Hadi selaku Manager Project, putusan nomor 104/PID.B/2012/PN.Tgr adalah terdakwa $\mathrm{H}$. Setiono, ST bin $\mathrm{H}$. Ponidi selaku PPTK (pejabat pelaksana tekhnis kegiatan), putusan nomor 105/PID.B/2012/PN.Tgr adalah terdakwa H. Yoyo Suryana, ST.MT bin Sali Afandi selaku kuasa pengguna anggrana (KPA) sekaligus pejabat pembuat komitmen (PPK) yang identitasnya sama dengan identitas dalam berkas perkara.

Mengenai subjek hukum tindak pidana, Teguh Prasetyo mengatakan bahwa rumusan tindak pidana didalam buku kedua dan ketiga KUHP biasanya dimulai dengan kata barangsiapa, ini mengandung arti bahwa yang dapat melakukan tindak pidana atau subjek hukum tindak pidana pada umumnya adalah manusia.

Dilihat dari ancaman pidana yang dijatuhkan sesuai dengan Pasal 10 KUHP, seperti pidana mati, pidana penjara, pidana kurungan, denda dan pidana tambahan mengenai pencabutan hak, dan sebagainya menunjukkan bahwa yang dapat dikenai sanksi pada umumnya manusia atau person. ${ }^{12}$

Dalam pergaulan hukum di tengahtengah masyarakat, ternyata manusia bukan satu-satunya subjek hukum (pendukung hak dan kewajiban), tetapi masih ada subjek hukum lain yang sering disebut badan hukum (rechtspersoon). ${ }^{13}$

Korporasi adalah termonologi yang biasa digunakan dalam hukum pidana untuk menyebut badan hukum (rechtpersoon atau legal entity) yang sudah melembaga dalam bidang hukum perdata. $^{14}$

Menurut Moeljatno, bahwa pertanggungjawaban pidana tidak cukup dengan dilakukannya perbuatan pidana saja, akan tetapi disamping itu harus ada kesalahan atau sikap batin yang dapat dicela, di dalam asas hukum disebutkan tidak dipidana jika tidak ada kesalahan

\footnotetext{
${ }^{12}$ Rinto Wardana, Op. Cit, Hlm. 93

13 Toto Tohir Suriaatmadja, Ujang Charda, Transpormasi Hukum Perdata Indonesia Dari Kodifikasi Ke Sektoral, Fakultas Hukum Universitas Subang, Subang, 2014, Hlm. 25 ${ }^{14}$ Edi Setiadi, fungsionalisasi Hukum Pidana Terhadap Kejahatan Korporasi, Syiar Madani Jurnal Ilmu Hukum Vol. III No. 1 Fakultas Hukum Unisba, 1 Maret 2002, Hlm. 63
} 
(geen straf zonder schuld, onhe schuld keine strafe). ${ }^{15}$

Di dalam doktrin tentang pertanggungjawaban pidana adalah keharusan adanya kesalahan, namun demikian, syarat umum adanya kesalahan itu dalam doktrin yang dianut di beberapa negara dikecualikan untuk tindak pidana tertentu, yaitu apa yang dikenal dengan strict liability dan vicarious liability. ${ }^{16}$

Penerapan ajaran kesalahan dalam Putusan Nomor 103/PID.B/2012/PN.Tgr, disebutkan bahwa :

"Terdakwa Muhammad Syahriar Fakhrurrozi kurang hati-hati atau waspada dimana terdakwa dapat membayangkan akibat yang akan terjadi dan melakukan pencegahan, sebagai Project Manager pemeliharaan jembatan Kutai Kartanegara, terdakwa mempunyai tanggungjawab yaitu memastikan kegiatan proyek berjalan sesuai dalam kontrak, menunjuk dan mengkoordinir personil sesuai lingkup pekerjaan dalam proyek, bertanggungjawab terhadap pekerjaan personil sesuai rencana teknis, finansial dan kepuasan pelanggan.

\footnotetext{
${ }^{15}$ Moeljatno, Asas - Asas Hukum Pidana, Rineka Cipta, Jakarta, 1993, Hlm. 37

16 Barda Nawawi Arief, Perbandingan Hukum Pidana, Raja Grafindo Persada, Jakarta, 1998, Hlm. 40
}

Diketahui bahwa dalam proses pemeliharaan jembatan belum ada ijin atau persetujuan untuk melakukan penutupan jalan akan tetapi terdakwa telah mengarahkan pekerjaan dengan hanya melalui telepon tanpa melakukan pengendalian secara langsung dilokasi pekerjaan. Terdakwa memerintahkan personilnya untuk melakukan peng-jackan chamber lantai jembatan dari titik bentang jembatan dengan cara di dongkrak setinggi per $2 \mathrm{~cm}$ toleransi 1 cm sehingga maksimal $3 \mathrm{~cm}$. Terdakwa juga membiarkan pekerjaan dilakukan tanpa memperhitungkan faktor keamanan dan keselamatan pengguna jalan. Terdakwa tahu bahwa secara teknis ijin buka tutup jembatan belum dikeluarkan oleh Bupati dan menghentikan pekerjaan akan tetapi mengabaikannya, sehingga dengan demikian, unsur karena salahnya telah terpenuhi".

Dalam ilmu hukum, bahwa agar suatu perbuatan dapat dianggap sebagai kelalaian, haruslah memenuhi unsur pokok sebagai berikut :

1. Adanya suatu perbuaan atau mengabaikan sesuatu yang semestinya dilakukan.

2. Adanya suatu kewajiban kehatihatian (duty of care) 
3. Tidak dijalankan kewajiban kehati-haian tersebut.

4. Adanya kerugian bagi orang lain.

5. Adanya hubungan sebab akibat antara perbuatan atau tidak melakukan perbuatan dengan kerugian yang timbul. ${ }^{17}$

Menimbang, bahwa selain itu juga, terhadap serangkaian peran yang telah terdakwa lakukan bersama-sama dengan Sdr. H. Setiono, ST dan sdr. Muhammad Syahriar Fakhrurrozi, ST., dilakukan atas dasar adanya kesepakatan, dimana terdakwa selaku KPA telah menunjuk / memilih H. Setiono, ST., untuk menjadi PPTK dalam pelaksanaan, kemudian dengan adanya peran masing-masing pihak, baik itu sdr. H. Setiono, ST selaku PPTK (pejabat pelaksana tekhnis kegiatan) dan sdr. Muhammad Syahriar Fakhrurrozi, ST. selaku kontraktor pelaksana dari PT. Bukaka Teknik Utama, yang saling bekerja sama yakni mulai dari proses perencanaan, dimana terdakwa selaku KPA dan PPK proyek meminta H. Setiono, ST selaku PPTK (pejabat pelaksana tekhnis kegiatan) untuk melakukan pembuatan / proses perencanaan, yakni dengan membuat atau

\footnotetext{
17 Munir Fuady, Perbuatan Melawan Hukum Pendekatan Kontemporer, Citra Aditya Bakti, Bandung, 2005, Hlm. 73
}

menentukan jenis pekerjaan dan menyusun HPS (harga perkiraan sendiri), baik dari segi teknik metode pemeliharaan jembatan serta metode mengenai safety / keamanan pekerjaan. Selanjutnya dilakukanlah proses pelelangan proyek yang dipersiapkan oleh H. Setiono, ST.,atas persetujuan terdakwa hingga dibentuklah pemenang lelang yakni PT. Bukaka Teknik Utama, kemudan dikeluarkanlah surat perjanjian kerja konstruksi (kontrak) nomor :2285/630/DPU/X/2011, tanggal 11 oktober 2011, yang kemudian ditandatangani oleh terdakwa selaku KPA/PPK dan sdri. Sofiah Balfas (Direktur PT. Bukaka Teknik Utama), dan surat perintah mulai kerja (SPMK) yang memerintahkan pekerjaan tersebut dimulai pada tanggal 12 oktober 2011 sampai dengan tanggal 12 desember 2011, disertai dengan surat penyerahan lapangan tanggal 12 oktober 2011 dari kuasa pengguna anggaran /PPK (terdakwa) kepada PT. Bukaka Teknik Utama yang diterima oleh Ir. Sofiah Balfas (Direktur PT. Bukaka Teknik Utama), hingga akhirnya ditunjuklah sdr. Muhammad Syahriar Fakhrurrozi,ST. selaku project manager pekerjaan kegiatan pemeliharaan jembatan Kutai 
Kartanegara, yang secara jelas dan rinci memiliki tugas dan tanggungjawab (nomor: :2285/630/DPU/X/2011, tanggal 11 oktober 2011, yakni melaksanakan pekerjaan diantaranya memastikan kegiatan proyek berjalan sesuai dengan ketentuan yang telah ditetapkan dalam kontrak menunjuk dan mengkoordinir personil sesuai dengan lingkup pekerjaan yang ada dalam proyek, memastikan pekerjaan personil sesuai dengan rencana baik dari segi tekhnis, finansial dan kepuasan pelanggan, kemudian dengan kewenangan tersebut, lalu sdr. Muhammad Syahriar Fakrurrozi,ST melakukan serangkaian pekerjaan, yakni mulai dari melakukan mobilisasi alat atau pekerja ke lokasi kerja dengan memerintahkan atau melalui koordinasi sdr. Makmur Azis yang ditunjuk oleh sdr. Muhammad Syahriar Fakrurrozi,ST dan diketahui oleh H. Setiono,ST selaku PPTK, serta membuat struktur organisasi atau daftar personil proyek pemeliharaan jembatan Kutai Kartanegara (termasuk menunjuk sdr. Makmur Azis) maupun panduan manual inspeksi beserta surat permohonan penutupan akses jembatan dan pembukaan outlet power listrik PLN yang dikoordinasikan / disetujui oleh terdakwa maupun sdr. H. Setiono, ST sampai dalam pelaksanaan pekerjaan berupa pemasangan dudukan jack pada posisi tengah-tengah jembatan Kutai Kartanegara, pekerjaan tersebut telah dilaporkan / disetujui oleh sdr. Setiono,ST selaku PPTK maupun sdr. Muhammad Syahriar Fakrurrozi, ST selaku Project Manager, dimana pelaporan / pemeriksaan metode kerja pelaksanaan pemeliharaan jembatan Kutai Kartanegara yang disampaikan oleh sdr. Makmur Azis kepada Muhammad Syahriar Fakrurrozi, ST melalui email atau telepon, kepada $\mathrm{H}$. Setiono,ST selaku PPTK langsung datang dan melihat sendiri kerjaan di lokasi kerja tersebut, namun mengesampingkan ketentuan sebagaimana yang telah diatur dalam kontrak maupun peraturan yang berlaku, misalnya menyerahkan fungsi pengawasan kepada orang lain sdr. Sugyana yang bukan sebagai pengawas.

Berdasarkan kronologis peran masing-masing pelaku, dapat terlihat bahwa tindakan yang dilakukan oleh salah satu pelaku memberikan konstribusi terjadinya suatu tindak pidana yang menimbulkan tanggungjawab pada pelaku yang lainnya. Hal tersebut dapat dilihat dalam dakwaan yang dibuat oleh Penuntut Umum, yaitu putusan nomor 
103/PID.B/2012/PN.Tgr adalah Muhammad Syahriar Fakhrurrozi, ST bin Noor Hadi selaku Manager Project, putusan nomor 104/PID.B/2012/PN.Tgr adalah terdakwa H. Setiono, ST bin H. Ponidi selaku PPTK (pejabat pelaksana tekhnis kegiatan), putusan nomor 105/PID.B/2012/PN.Tgr adalah terdakwa H. Yoyo Suryana, ST.MT bin Sali Afandi selaku kuasa pengguna anggrana (KPA) sekaligus pejabat pembuat komitmen (PPK) (masing-masing penuntutan secara terpisah).

Menurut Chairul Huda, terdapat dua hal yang memungkinkan korporasi sebagai pelaku tindak pidana (pleger), yaitu : ${ }^{18}$

1. Dalam hubungan penyertaan yang umum (nonvicarious liability crime)

Dalam hubungan ini, pelaku materiilnya adalah pimpinan korporasi, yaitu mereka yang mempunyai kedudukan untuk menentukan kebijakan dalam korporasi. Dilihat dari hubungan penyertaan yang umum sebagaimana dimaksud dalam

18 Yusuf Shofie, Tanggung Jawab Pidana Korporasi Dalam Hukum Perlindungan Konsumen Di Indonesia, Citra Aditya Bakti, Bandung, 2011, Hlm. 413
Pasal 55 KUHP, maka korporasi sebagai pembuat tindak pidana.

2. Dalam hal hubungan penyertaan (vicarious liability crime)

Dalam hubungan ini, pelaku materiilnya adalah bawahan atau tenaga-tenaga pelaksana atau pegawai yang bertindak dalam kerangka kewenangannya dan atas nama korporasi. ${ }^{19}$

Dimana dalam hal ini ketiga putusan Majelis Hakim belum menjangkau subjek hukum korporasi sebagai subjek hukum yang dapat dipertanggungjawabkan.

Konsep pertanggungjawaban pidana korporasi yang sebaiknya digunakan dalam kasus ini yaitu pengurus dan korporasi keduanya sebagai pelaku tindak pidana dan keduanya pula yang harus memikul pertanggungjawaban pidana. Hal ini sebagaimana yang dikemukakan oleh Sutan Remy Sjahdeini, dengan berbagai alasan antara lain $:^{20}$

1) Apabila hanya pengurus yang dibebani pertanggungjawaban

\footnotetext{
19 Yusuf Shofie, Tanggungjawab Pidana Korporasi Dalam Hukum Perlindungan Konsumen Di Indonesia, Ibid

${ }^{20}$ Kristian, Urgensi Pertaggungjawaban Pidana Korporasi, Jurnal Hukum dan Pembangunan Tahun ke-44 No.4 Oktober-Desember 2013, Hlm. 614
} 
pidana, maka menjadi tidak adil bagi masyarakat yang telah menderita kerugian karena pengurus dalam melakukan perbuatannya itu adalah untuk dan atas nama korporasi serta dimaksudkan untuk memberikan keuntungan atau menghindarkan mengurangi kerugian finansial bagi korporasi.

2) Apabila yang dibebani pertanggungjawaban pidana hanya korporasi sedangkan pengurus tidak harus memikul tanggung jawab, maka sistem ini akan dapat memungkinkan pengurus bersikap "lempar batu sembunyi tangan" atau mengalihkanpertanggungjawaban. Dengan kata lain, pengurus akan selalu dapat berlindung di balik punggung korporasi untuk melepaskan dirinya dari tanggung jawab dengan dalih bahwa perbuatannya itu bukan merupakan perbuatan pribadi dan bukan untuk kepentingan pribadi, tetapi merupakan perbuatan yang dilakukannya untuk dan atas nama korporasi dan untuk kepentingan korporasi.
3) Pembebanan pertanggungjawaban pidana kepada korporasi hanya mungkin secara vikarius, atau bukan langsung (doctrine of vicarious liability), pertanggungjawaban atas tidak pidana yang dilakukan oleh seseorang dibebankan kepada pihak lain. Dalam hal pertanggungjawaban pidana, korporasi dialihkan pertanggungjawaban pidananya kepada korporasi. Pembebanan pertanggungjawaban pidana kepada korporasi hanya mungkin dilakukan secara vikarius karena korporasi tidak mungkin dapat melakukan sendiri suatu perbuatan hukum. Artinya, segala perbuatan hukum yang benar atau yang salah baik dalam lapangan keperdataan maupun yang diatur oleh ketentuan pidana, dilakukan oleh manusia yang menjalankan kepengurusan korporasi. ${ }^{21}$

\section{Implementasi}

Pertanggungjawaban Pidana Kontraktor Atas Terjadinya Insiden Runtuhnya Jembatan

\footnotetext{
${ }^{21}$ Kristian, Urgensi Pertaggungjawaban Pidana Korporasi, Ibid
} 


\section{Kutai Kartanegara \\ Berdasarkan Peraturan \\ Mahkamah Agung No 13 \\ Tahun 2016 Tentang Tata Cara \\ Penanganan Perkara Tindak \\ Pidana Oleh Korporasi}

Di dalam Peraturan Mahkamah Agung Nomor 13 Tahun 2016 Tentang Tata Cara Penanganan Perkara Tindak Pidana Oleh Korporasi, di dalam pertimbangannya mengatakan bahwa :

a. Korporasi sebagai suatu entitas atau subjek hukum yang keberadaannya memberikan konstribusi yang besar dalam meningkatkan pertumbuhan ekonomi dan pembangunan nasional, namun dalam kenyatannya korporasi ada kalanya melakukan berbagai tindak pidana (corporate crime) yang membawa dampak kerugian terhadap negara dan masyarakat.

b. bahwa banyak undang-undang di Indonesia menempatkan korporasi sebagai subjek tindak pidana yang dapat dimintai pertanggungjawaban, namun perkara dengan subjek hukum korporasi yang diajukan dalam proses pidana masih sangat terbatas, salah satu penyebabnya adalah prosedur dan tata cara pemeriksaan korporasi sebagai pelaku tindak pidana masih belum jelas, oleh karena itu dipandang perlu adanya pedoman bagi aparat penegak hukum dalam penanganan perkara pidana yang dilakukan oleh korporasi.

Menurut Sudarto, politik kriminal adalah usaha rasional untuk menanggulangi kejahatan. Menurut Barda Nawawi Arief, politik kriminal merupakan bagian dari politik perlindungan sosial (social policy defense) semua merupakan dari politik sosial (social policy), oleh karena itu tujuan utama dari politik kriminal adalah perlindungan masyarakat untuk mencapai kesejahteraan masyarakat. $^{22}$

Dalam upaya penanggulangan tindak pidana korporasi, maka perlunya kebijakan kriminal dengan menggunakan sarana penal (hukum pidana) artinya mengupayakan suatu penanggulangan kejahatan dengan menggunakan hukum pidana (menitikberatkan pada sifat represif) yang dilakukan melalui sistem

22 Dini Dewi Heniarti, Kriminalisasi Dalam Hukum Pidana, Makalah, Fakultas Hukum UNISBA, 1998, Hlm. 4 
peradilan pidana. $^{23}$ Namun, pendekatan penal ini harus dilakukan dengan hatihati, maka penting mempertimbangkan atau memperhatikan asas ultimatum remedium. ${ }^{24}$

Upaya penanggulangan kejahatan dengan menggunakan jalur non penal bersifat sebagai upaya pencegahan kejahatan (preventive) yang sasaran utamanya adalah menangani faktor-faktor kondusif penyebab terjadinya kejahatan. Upaya ini berkaitan dengan langkah yang bernuansa teknis pencegahan seperti diterapkannya pedoman-pedoman tertentu misalnya code of conduct, code of ethics dan code of practice. ${ }^{25}$

PT. Bukaka Teknik Utama dan pengurus-pengurusnya yang merupakan subjek hukum yang dapat dimintakan pertanggungjawaban pidana serta penjatuhan pidana baik pidana pokok maupun pidana tambahan terhadap insiden runtuhnya jembatan Kutai Kartanegara yang mengakibatkan orang lain meninggal dunia dan luka-luka, berdasarkan Peraturan Mahkamah Agung Nomor 13 tahun 2016 Tentang Tata Cara

\footnotetext{
${ }^{23}$ Dey Ravena, Kristian, Kebijakan Kriminal, Op. Cit, Hlm. 9

${ }^{24}$ Dey Ravena, Kristian, Kebijakan Kriminal, Ibid, Hlm. 10

25 Dey Ravena, Kristian, Kebijakan Kriminal, Ibid, Hlm. 18
}

Penanganan Perkara Tindak Pidana Oleh Korporasi maka seharusnya dan Sdri. Sofiah Balfas sebagai Direktur PT. Bukaka Teknik Utama dapat dimintai keterangannya atau kesaksiannya, tetapi dalam ketiga putusan Majelis Hakim tidak dilakukan sehingga keadaan tersebut bertentangan dengan teori pertanggungjawaban pidana doktrin vicarious liability dalam kasus ini karena vicarious liability ini berlaku terhadap delik-delik yang mensyaratkan kualitas, delik-delik yang mensyaratkan adanya hubungan antara buruh dan majikan. Selain itu korporasi dalam hal ini PT. Bukaka Teknik Utama terbukti melanggar ketentuan sebagaimana diuraikan di dalam Pasal 4 yaitu :

a. Korporasi dapat memperoleh keuntungan atau manfaat dari tindak pidana tersebut atau tindak pidana tersebut dilakukan untuk kepentingan korporasi;

b. Korporasi membiarkan terjadinya tindak pidana; atau

Korporasi tidak melakukan langkah-langkah yang diperlukan untuk melakukan pencegahan, mencegah dampak yang lebih besar dan memastikan kepatuhan terhadap ketentuan hukum yang 
berlaku guna menghindari terjadinya tindak pidana.

Sunar Jaya mengemukakan bahwa Perma ini akan menciptakan kepastian hukum, jadi sudah jelas jika dulu pertanggungjawaban korporasi masih didasarkan pengalaman penegak hukum. Tahun 1955 korporasi dihukum dengan cara pengampuan, ada juga yg menghukum korporasi dengan kurungan. Di dalam Perma sudah tegas mengangkat undang-undang bahwa 100 undangundang memungkinkan korporasi diberi sanksi. Ada 2 sanksi yaitu denda dan pidana tambahan (sanksi pencabutan ijin). Ruhnya Rerma tercantum dalam Pasal 3 tentang actus reus dan mens rea. Penting bagaimana korporasi melakukan perbuatan pidana, korporasi tidak ada wujud dan tidak ada nyawa. Pasal 3 mengatur tentang siapa yang dimintai tanggungjawab korporasi, jadi Pasal 3 menganut setidaknya ada 2 doktrin, yaitu:

1. Setiap perbuatan pengurus adalah menjadi perbuatan korporasi, jadi simbol korporasi ada dipengurus, yang dianut dalam rancangan KUHP kurang tepat jika KUHP kita hanya menganut identifikasi maka orang lain atau karyawan jika berbuat untuk kepentingan perusahaan maka tidak di hukum itulah kelemahannya maka hanya orang-orang yang ada di anggaran dasar yang bisa dihukum. Identifikasi adalah orang-orang secara format yang termuat dalam anggraan dasar, jika ini yg terjadi maka banyak tapi atas nama korporasi tidak dijerat.

2. Orang yang secara de facto mengendalikan itu kelompok pertama bisa dijerat dalam Perma. Kelompok kedua, karyawan yang berbuat karena hubungan kerja di Pasal 3 dijelaskan bahwa ketika berbuat untuk kepentingan sesuai dengan kepentingannya maka bisa dijerat. Teori responden superior yg digunakan amerika lebih mudah untuk menjerat korporasi dengan menggunakan teori ini, turunan dari vicarious liability. Bagaimana jika perusahaan dengan yang memberi kuasa, di indonesia 
banyak, maka sudah diatur dalam perma. ${ }^{26}$

Hukum Islam telah mengenal adanya pertanggungjawaban pidana korporasi, dalam hal ini hukum islam mengutamakan kepentingan umum yaitu menjamin terwujudnya lima dasar kemaslahatan umat, yaitu khifd al-nafs, khifd al-aql, khifd al-mal, khifd al-din, khifd al-nasb dan jika dilihat dari dampak terhadap masyarakat yang ditimbulkan oleh kejahatan yang dilakukan oleh atau atas nama korporasi maka setiap tindakan yang dilakukan setiap insan yang berakal sehat pasti memiliki maksud dan tujuan. Apalagi Allah SWT, sang maha pencipta yang maha berkehendak, pastilah segala tindakan-Nya dilandasi oleh maksud dan tujuan. Allah SWT menetapkan syariat yang paling agung untuk umat manusia, juga memiliki maksud dan tujuan. Dalam bahasa Arab, maksud dan tujuan ini disebut maqsad yang bentuk jamaknya adalah maqasid. Dengan merangkaikan kata maqasid dengan kata syari'ah menjadi maqasidusy-syari'ah, tercipta pengertian maksud-maksud dan tujuan syariat. Yusuf Hamid al-Alim

\footnotetext{
${ }^{26}$ http://pasca.unair.ac.id/implementasi-perma-no13-tahun-2016-dalam-seminar-nasional-potensidan-prospek-pemidanaan-korporasi/, diakses pada tanggal 13 April 2019
}

mendefinisikan maqasidusy-syari'ah sebagai tujuan yang akan dicapai oleh penetapan syariat dan rahasia-rahasia yang diletakan oleh Allah SWT sebagai pembuat syariat yang maha bijaksana dalam setiap hukum. ${ }^{27}$

\section{PENUTUP}

\section{Kesimpulan}

Berdasarkan teori pertanggungjawaban pidana, dengan adanya pergeseran subjek hukum dari fysieke dader ke functionale dader maka korporasi dapat dimintakan pertanggungjawaban. Hal tersebut juga didukung dengan adanya teori-teori serta doktrin-doktrin tentang pertanggungjawaban korporasi. Namun, dalam implementasinya Penanganan Perkara Tindak Pidana Oleh Korporasi masih sangat minim dalam prakteknya. Dengan adanya PERMA tersebut Sehingga, dapat mendorong efektivitas dan optimalisasi atas hukum acara dalam penangangan perkara pidana dengan pelaku korporasi dan/atau pengurus korporasi.

\section{Saran}

\footnotetext{
${ }^{27}$ Kementrian Agama RI, Maqasidusy-Syari'ah Memahami Tujuan Utama Syariah, Jakarta, Lajnah Pentasbihan Mushaf Al-Quran, 2013, Hlm. 16
} 
Berdasarkan teori-teori serta doktrin pertanggungjawaban pidana, maka seharusnya korporasi dapat dimintakan pertanggungjawabannya. diperlukan adanya aturan khusus yang mengatur tindak pidana korporasi karena di dalam PERMA No 13 Tahun 2016 Tentang Tata Cara Penanganan Perkara Tindak Pidana Oleh Korporasi hanya mengatur tentang tata cara yang tetap merujuk kepada undang-undang yang mengatur tentang korporasi.

\section{DAFTAR PUSTAKA}

Agus Rusianto, 2016, Tindak Pidana dan Pertanggungjawaban Pidana Tinjauan Kritis Melalui Konsistensi Antara Asas, Teori dan Penerapannya, Prenadamedia Group, Jakarta

Barda Nawawi Arief, 1998, Perbandingan Hukum Pidana, Raja Grafindo Persada, Jakarta

Dey Ravena, Kristian, 2017, Kebijakan Kriminal, Kencana, Jakarta

Dini Dewi Heniarti, 1998, Kriminalisasi Dalam Hukum Pidana, Makalah, Fakultas Hukum UNISBA

Dwidja Priyatno, 2003, Kebijakan Legislasi Tentang Sistem Pertanggungjawaban Pidana Korporasi Di Indonesia, CV Utomo, Bandung
Edi Setiadi, 2002, fungsionalisasi Hukum Pidana Terhadap Kejahatan Korporasi, Syiar Madani Jurnal Ilmu Hukum Vol. III No. 1 Fakultas Hukum Unisba, 1 Maret

Edi Setiadi, Kristian, 2017, Sistem Peradilan Pidana Terpadu Dan Sistem Penegakan Hukum Di Indonesia, Kencana, Jakarta

Hana Pritanti, Purwoto, Solechan, 2012, Pertanggungjawaban Pidana Terhadap Kontraktor Dalam Hal Terjadi Kecelakaan Kerja Menurut Undang-Undang No. 3 Tahun 1992 Tentang Jaminan Sosial Tenaga Kerja,Volume 1 Nomor 4.

http://pasca.unair.ac.id/implementasiperma-no-13-tahun-2016-dalamseminar-nasional-potensi-danprospek-pemidanaan-korporasi/, diakses pada tanggal 13 April 2019

http://www.tribunnews.com/nasional/201 8/01/16/ini-analisa-pemicuambrolnya-selasar-tower-2-beiversi-gapensi, diakses pada tanggal 29 Maret 2018 pukul 10:50 wib.

Juniarso Ridwan, Achmad Sodik Sudrajat, 2014, Hukum Administrasi Negara Dan Kebijakan Layanan Publik, Nuansa Cendekia, Bandung

Kementrian Agama RI, 2013, Maqasidusy-Syari'ah Memahami Tujuan Utama Syariah, Jakarta, Lajnah Pentasbihan Mushaf AlQuran

Kristian, 2016, Kejahatan Korporasi Di Era Modern \& Sistem Pertanggungjawaban Pidana 
Korporasi, Refika Aditama, Bandung

Kristian, Urgensi Pertaggungjawaban Pidana Korporasi, Jurnal Hukum dan Pembangunan Tahun ke-44 No.4 Oktober-Desember 2013

Moeljatno, 1993, Asas - Asas Hukum Pidana, Rineka Cipta, Jakarta

Munir Fuady, 2005, Perbuatan Melawan Hukum Pendekatan Kontemporer, Citra Aditya Bakti, Bandung

Putusan Pengadilan Nomor : 103/PID.B/2012/PN. Tgr

Rinto Wardana, 2016, Tanggungjawab Pidana Kontraktor Atas Kegagalan Bangunan Menerobos Dominasi Maxim Societas/Universitas
Delinquere Non Potest, Media Nusa Creative, Malang

Rufinus Hotmaulana Hutauruk, 2014, Penanggulangan Kejahatan Korporasi Melalui Pendekatan Restoratif Suatu Terobosan Hukum, Sinar Grafika, Jakarta

Toto Tohir Suriaatmadja, Ujang Charda, 2014, Transpormasi Hukum Perdata Indonesia Dari Kodifikasi Ke Sektoral, Fakultas Hukum Universitas Subang, Subang

Yusuf Shofie, 2011, Tanggung Jawab Pidana Korporasi Dalam Hukum Perlindungan Konsumen Di Indonesia, Citra Aditya Bakti, Bandung 